\title{
PROSECUTION OF MOTHERS OF DRUG-EXPOSED BABIES: CONSTITUTIONAL AND GRIMINAL THEORY
}

\section{DORETTA MASSARDO MCGINNIS $\dagger$}

During the late 1980 s, a new prosecutorial trend developed: women who had used drugs during pregnancy and subsequently delivered drug-exposed babies were charged with a variety of crimes including criminal neglect, ${ }^{1}$ delivery of drugs to a minor, ${ }^{2}$ and involuntary manslaughter. ${ }^{3}$ It was estimated that eighteen such cases were pending nationwide as of October $1989,{ }^{4}$ representing an abrupt increase in the wake of the Supreme Court's July 1989 decision in Webster $v$. Reproductive Health Services. ${ }^{5}$ Early in 1990 the American Civil Liberties Union counted at least thirty-five cases across the country as this prosecutorial trend continued into the new decade. ${ }^{6}$

These prosecutions uniformly involve the application of laws previously applied to redress offenses committed against children

†A.B. 1985 Harvard University; J.D. Candidate 1991, University of Pennsylvania. Thanks to Barbara B. Woodhouse, Stephen J. Morse, Judith Bernstein-Baker, and Martin J. Doyle. This Comment is dedicated to David E. McGinnis.

${ }^{1}$ In 1986, Pamela Rae Stewart of El Cajon, Cal., was charged with criminal neglect after her alleged drug use during pregnancy and failure to take proper prenatal precautions resulted in the death of her child. Charges were eventually dropped. See Note, Of Woman's First Disobedience: Forsaking a Duty of Care to Her Fetus-Is This a Mother's Crime?, 53 BROOKLYN L. REv. 807, 807-08 (1987) (discussing People v. Stewarth tried in the San Diego Municipal Court). Pamela Stewart was the first American woman to be criminally charged with fetal neglect. See Sherman, Keeping Babies Free of Drugs, Nat'l L.J., Oct. 16, 1989, at l, col. 3.

2 Women charged with delivering drugs through their umbilical cords include Jennifer Johnson of Sanford, Fla., see infra notes 11-12 and accompanying text, Josephine Pellegrini of Brockton, Mass., see Coakley \& Hart, Mother Indicted on Cocaine Charge, Boston Globe, Sept. 27, 1989, at 31, col. 1, Kimberly Hardy of Muskegon County, Mich., see infra note 13 and accompanying text, and Lynn Bremer, also of Muskegon County, see Hoffman, Pregnant, Addicted-And Guilly?, N.Y. Times, Aug. 19, 1990, § 6 (Magazine), at 35.

${ }^{3}$ Melanie Green of Rockford, Ill., was charged with involuntary manslaughter in 1989. See infra note 8 and accompanying text.

${ }^{4}$ See Foster, Fetal Endangerment Cases Increase, Christian Sci. Monitor, Oct. 10, 1989, at 8, col. 2. By October 1989, cases had been brought in Arizona, California, Colorado, Florida, Indiana, Massachusetts, Ohio, and South Carolina. See id.

5109 S. Ct. 3040 (1989); see McNamara, Fetal Endangerment Cases on the Rise, Boston Globe, Oct. 3, 1989, at 1, col. 2 (linking the increase in prosecutions to a heightened interest in fetal rights following Webster).

${ }^{6}$ See Paltrow, When Becoming Pregnant is a Crime, 9 CRIM. Just. ETHICs 41 (1990). Women have been recently prosecuted in Kentucky and North Carolina, see Hoffman, supra note 2, at 35, as well as in the states indicated supra notes 2-4. 
after birth. 'Arguably, prosecutors have misconstrued existing statutes to create new offenses in contravention of legislative intent, while denying defendants the due process requirements of notice and fair warning. Several state legislatures have passed or are considering legislation specifically aimed at prohibiting and punishing the use of illicit drugs by pregnant women. Passage of such legislation will likely be accompanied by clear expressions of legislative intent, and potential defendants will likely be granted notice and fair warning. Other potential constitutional problems, however, will remain. The fundamental right to bear a child will be denied to a class of women-drug addicts-based on their status as addicts and the effects that their addictive behaviors are likely to have on their children. The rights of privacy and reproductive freedom currently accorcled all women may be further eroded. Such restrictions may, however, be found constitutional if courts accept the view that fetal rights outweigh women's rights in the context of a pregnant wornan's behavior likely to cause fetal harm.

Even if the current constitutional defects are remedied through the passage of narrowly tailored statutes and increased recognition of fetal rights, prosecutions of pregnant drug users still cannot be justified under prevailing theories of criminal law. These prosecutions may involve punishing women on two inappropriate grounds: their involuntary, addictive behavior and their status as pregnant addicts. Involuntary behavior typically does not justify punishment, and status crimes are categorically prohibited. The involuntary nature of addiction makes it unlikely that these prosecutions will have any significant deterrent effect. In the absence of general deterrence, these prosecutions will fail to benefit potential defendants, their children, or society as a whole. In fact, it is likely that criminogenic effects ${ }^{7}$ will ensue: crimes associated with the evasion of these prosecutions may increase; respect for the legal system may be diminished as the public observes the spectacle of the state prosecuting poor, disenfranchised drug users while the wealthy avoid prosecution and enjoy the benefits of discriminatory law enforcement; prosecutorial resources may be diverted from more effective uses (such as the prosecution of drug suppliers and dealers) to the prosecution of women whose children are already permanently drug-affected and who require medical, not penal, attention. Drug-addicted women and their actual and potential

${ }^{7}$ See infra text following note 107. 
children need medical help which the criminal justice system is neither designed nor equipped to provide.

In May 1989, Melanie Green of Rockford, Illinois became the first woman in the United States to be charged with manslaughter for the death of a baby who died (after being born alive) of complications resulting from prenatal maternal cocaine use. ${ }^{8}$ Green was also charged with delivering drugs to a minor. ${ }^{9}$ A Winnebago County grand jury refused to indict Green and all charges were dropped. ${ }^{10}$

In July 1989, the Seminole County Court in Sanford, Florida convicted Jennifer Johnson of delivering drugs to a minor. ${ }^{11}$ Johnson had used cocaine during her pregnancy and her child was born with traces of the drug in his system. An attempt to convict Johnson of child abuse was unsuccessful. The prosecutor ultimately applied a statute typically used against drug traffickers. Johnson was sentenced to fifteen years of probation, attendance at a drug rehabilitation program, and mandatory prenatal supervision should she become pregnant again. ${ }^{12}$

In August 1989, Kimberly Hardy of Muskegon County, Michigan gave birth to a son who tested positive for drugs. She was subsequently arrested and charged with delivering crack to her son through her umbilical cord. The Michigan Court of Appeals is currently deciding whether her case should be tried in a lower state court or dismissed. ${ }^{13}$

${ }^{8}$ See Reardon, Grand Jury Won't Indict Mother In Baby's Dreg Death, Chicago Tribune, May 27, 1989, at 1, col. 5. Green was charged under the Illinois involuntary manslaughter statute. See Logli, Drugs in the Womb: The Newest Battlefield in the War on Drugs, 9 CRIM. JuST. ETHICS 23, 24 (1990). The complaint read in part: "Melanie Green committed the offense of involuntary manslaughter in that she . . . killed her child ... by recklessly performing the act of ingesting a controlled substance containing cocaine while pregnant with [the child] .... Id. at 29 n.9.

${ }^{9}$ This charge was brought under Illinois' drug delivery statute, ILL. REV. STAT. ch. 56 1/2, para. 1407 (1987). See Logli, supra note 8, at 29 n.10. The complaint read in part: "Melanie Green committed the offense of violation of the controlled substances act in that she, a person over eighteen years of age, delivered to a person under eighteen years of age a controlled substance containing cocaine, to wit: while pregnant ... she knowingly ingested a controlled substance containing cocaine which was thereby delivered to the bloodstream and body of her fetus . ..." Id.

${ }^{10}$ See Reardon, supra note 8.

${ }^{11}$ See Paltrow, supra note 6, at 42, $46 \mathrm{n} .13$ (discussing State v. Johnson, tried in the Seminole County Court).

${ }^{12}$ See Linn, The Corruption of Motherhood, Phila. Inquirer, Sept. 17, 1989, Magazine, at 14.

${ }^{13}$ See Hoffman, supra note 2, at 34-35. 
This Comment will first discuss the constitutional ramifications of these prosecutions. It will then analyze the prosecutions in the context of criminal legal theory. Finally, the prosecutions will be discussed in the context of the national debates on abortion and drug abuse. This Comment concludes that the criminal justice system is ill-suited to intervene in the complex medical and sociological problems associated with drug use and pregnancy; which may be more effectively and humanely addressed by drug treatment programs for pregnant addicts.

\section{CONSTITUTIONAL ISSUES}

The constitutional concerns raised by the prosecution of mothers who have delivered drug-exposed babies are twofold. First, the unforeseeable application against pregnant drug abusers who harm their fetuses of statutes usually construed to protect live-born children does not satisfy the requirements of due process. Prosecutors have crafted new offenses that are not sanctioned by state legislatures, and potential defendants are subjected to criminal liability without notice or fair warning. Second, such prosecutions further expand fetal rights at an impermissible cost to women's rights. This section evaluates these two aspects of the dubious constitutionality of the recent prosecutions.

\section{A. Due Process Violations}

Prior to the spate of prosecutions at issue here, statutes criminalizing child abuse, manslaughter, or the delivery of drugs to a minor had been used against adults who abused, killed or sold drugs to children, not against mothers whose prenatal drug use caused fetal harm. ${ }^{14}$ The statutes typically use such terms as "child" or "person"; 15 their application in cases involving live-born children harmed after birth fell within the bounds of legislative intent $^{16}$ and avoided delicate determinations concerning the beginnings of "personhood." 17 Endorsement by the courts of

14 For example, the drug-delivery statute used against Jennifer Johnson had previously been used against drug dealers. See Chavkin, Help, Don't Jail, Addicted Mothers, N.Y. Times, July 18, 1989, at A21, col. 2.

15 See, e.g., FLA. STAT. ANN. $\$ 893.13(1)(a)(3)(c)$ (West 1976) (criminalizing delivery of drugs to "a person under the age of 18 years"); ILL. ANN. STAT. ch. 56 1/2, para. 1407 (Smith-Hurd 1985 \& Supp. 1990) (same).

${ }^{16} \mathrm{~A}$ child born alive is indisputably a person under 18 years of age, regardless of whether a child conceived but not yet born is such a person.

${ }^{17}$ See infra note 26 and accompanying text (discussing how prosecutors have 
prosecutors' applications of such statutes to mothers who have harmed their fetuses by using drugs during pregnancy may, however, constitute the impermissible judicial creation of new offenses. The legislature, not the courts, should create new offenses. ${ }^{18}$ In addition, the prosecuted mothers were not on notice that their activity was a crime vis-à-vis their fetuses. This unforeseeable classification of certain acts as offenses is a violation of the constitutional requirements of notice and fair warning. The requirements of due process that (1) the legislature, not the courts, define crimes and (2) potential defendants be granted notice or fair warning that their conduct is criminal are considered below.

\section{Legislative Definitions of Crimes}

The Supreme Court of California provided an instructive discussion of the role of the legislature in defining crimes in the landmark case of Keeler v. Superior Court. ${ }^{19}$ The defendant, charged with murder in connection with the stillbirth of a baby that had suffered a fractured skull in utero, had beaten the child's mother during the eighth month of pregnancy with the intent to kill the fetus.

The California court began by noting the language of the state's murder statute, which proscribed the "unlawful and malicious killing of a human being ...."20 Examining legislative intent, the court concluded that a fetus was not a human being within the meaning of the statute; the defendant, therefore, was not guilty of murder. ${ }^{21}$ The Keeler court stated that "the power to define crimes and fix penalties is vested exclusively in the legislative branch. ... [ [T] he courts cannot go so far as to create an offense by enlarging a statute ... or by giving the terms used false or unusual meanings."22 Given the codification of criminal law in the United States and the attendant demise of common law crimes, these statements describe the general American rule, not simply the law of California. ${ }^{23}$ The California state legislature responded to the

evaded making "personhood" determinations by contending that drugs can be delivered through the uncut umbilical cord after birth).

${ }^{18}$ See infra notes 31-41 and accompanying text (surveying several states' legislative reactions to these prosecutions and discussing possible legislative solutions).

192 Cal. 3d 619, 470 P.2d 617, 87 Cal. Rptr. 481 (1970).

$20 \mathrm{Id}$. at 624, 470 P.2d at 619, 87 Cal. Rptr. at 483 (quoting CAL. PENAL CodE $\S 187$ (1872) (amended 1970) (emphasis added)).

21 See id. at 623,470 P.2d at 618, 87 Cal. Rptr. at 482.

22 Id. at $631-32,470$ P.2d at 624-25, $87 \mathrm{Cal}$. Rptr. at $488-89$ (citations omitted).

23 See S. Kadish, S. SchulHofer \& M. PAUlsEN, CRIMINAL LAW AND ITS 
Keeler decision by revising the state's murder statute to encompass feticide. ${ }^{24}$

Fair application of a statute in a manner consistent with legislative intent requires an inquiry into the meaning of the statutory terms. In Keeler, for example, the court had to determine whether a fetus came within the statutory term "human being." One issue raised by the current prosecutions of mothers who bear drug-exposed babies is whether the fetuses are "children" or "persons" within the meaning of the applied statutes. For example, the drug delivery complaint against Melanie Green characterized her fetus as a person under eighteen years of age. ${ }^{25}$ Several prosecutors have evaded considerations of legislative intent by arguing that drugs were delivered to a child born alive via the umbilical cord in the moments before the cord was clamped. ${ }^{26}$ If a fetus was not intended by the legislature to come within the ambit of a statutory term such as "person," this application of the statute to cases of fetal harm may constitute the creation of a new offense by enlarging the statute to encompass harm to fetuses as well as to persons, or by according an unusual or unintended meaning to the term "person." Either of these consequences would constitute prosecutorial usurpation of the legislature's power to define crimes.

Processes 354 (4th ed. 1983).

${ }^{24}$ See CAL. PENAL CoDE $§ 187$ (West 1988).

${ }^{25}$ See supra note 9.

${ }^{26}$ See, e.g., Paltrow, supra note 6, at 42 (describing the prosecutor's argument in the Johnson case); Hoffman, supra note 2, at 34 (describing the prosecutor's contention in the Hardy case and noting that such arguments "avoid . . . debates over when the fetus becomes a person"). The personhood debate, however, is unavoidable when drug exposture occurred well before birth, so that drug metabolites could not be passed through the umbilical cord after birth.

Dr. Ira J. Chasnoff, founder and president of the National Association of Perinatal Addiction Research and Education, questions the medical validity of the theory that cocaine can be passed through the umbilical cord immediately before it is clamped. He has said, "Good ethics and good law have to be based on good science . . . and we just don't have that kind of data." Id. at 35.

It should be noted that finding that a fetus is a person within the meaning of a state statute could be constitutional, and would contravene neither Roe v. Wade, 410 U.S. 113 (1973) (which held that a fetus is not a person under the fourteenth amendment) nor Webster v. Reproductive Health Services, 109 S. Ct. 3040 (1989) (which left Roe's fourteenth amendment holding intact). See infra text accompanying notes $42-45$. Such a finding, though constitutional, may still be violative of legislative intent.

This Comment will presume that the state legislatures in question did not intend to include fetuses within the ambits of the statutes currently being used to prosecute pregnant drug users. 
While an analysis of the legislative history of the relevant statutes in each state where prosecutions have occurred is beyond the scope of this Comment, it is apparent that prosecutors have applied laws in novel ways. In the Green case, prosecutor Paul Logli "sought to apply the involuntary manslaughter statute because there [were] no laws in Illinois directly applicable to the case."27 Logli himself has speculated that the grand jury failed to indict Green because "the jurors were uncomfortable with the use of statutes that were not intended to be used in these circumstances." 28 Such prosecutorial initiatives may contravene legislative intent and ostensibly create new offenses of fetal harm. ${ }^{29}$ Creation of offenses is a role that is properly assumed by the legislature, not prosecutors. $^{30}$

It is possible that state legislatures will respond to the courts' failure to convict pregnant drug users under existing statutes by passing laws that are more narrowly tailored to prosecutorial goals. The statutory definition of a child or person may be expanded to include fetuses, ${ }^{31}$ or the definition of abuse or neglect may be

${ }^{27}$ Wilkerson, Jury in Illinois Refuses to Charge Mother in Drug Death of Newborm, N.Y. Times, May 27, 1989, at A10, col. 5.

${ }^{28}$ Logli, supra note 8 , at 24.

29 With regard to the current spate of prosecutions, it has been argued that state laws have been construed in flagrant violation of legislative intent. Walter Connolly, Jr., a lawyer representing the National Association for Perinatal Addiction Research and Education, states that "[t]he law is clear that it is unconstitutional to prosecute women who use drugs when pregnant when the sole issue is harm to the fetus under existing state law." Foster, supra note 4, at 8, col. 2. Harvard law professor Alan Dershowitz notes that "Massachusetts has a statute saying it's a crime to transmit drugs . . . . Every legislator voted for that. No one dreamed it would be applied to women taking drugs while pregnant." Id.

${ }^{30}$ See supra notes $22-23$ and accompanying text.

31 In order for a statute to be used with a sound legal basis against a woman whose prenatal behavior harms her fetus, the statute should include language or legislative history that supports such application; merely stating that the law encompasses fetal harm is insufficient, as is shown by the case of People v. Stewart. See supra note 1. Stewart was charged with criminal neglect under a statute that makes it a misdemeanor for a parent to "willfully omit[] without lawful excuse, to furnish necessary clothing, food, shelter or medical attendance, or other remedial care for his or her child" and states that a "child conceived but not yet born is an existing person insofar as this section is concerned." CAL. PENAL CODE $\$ 270$ (West 1988). Althougl Stewart had allegedly injured a "child conceived but not yet born," charges were dismissed for failure to state a charge: the judge ruled that the state legislature intended the law to be used only to require child support. See A Judge Dismissed Thursday the Criminal Prosecution of a Mother Accused of Contributing to Her Baby's Death, UPI, Feb. 26, 1987, AM cycle, Domestic News (LEXIS, Nexis library, UPI file). Stewart's attorney, Lynn Paltrow of the ACLU, argued that the statute was intended to require fathers to pay for pregnancy care. See id. The statute had been amended 
amended to mention explicitly maternal drug use during pregnancy. To date, most legislative responses have been in the area of civil, rather than criminal, law. After the refusal of an Illinois grand jury to indict Melanie Green for manslaughter after her newborn died of complications stemming from maternal drug use, the state legislature expanded the statutory definition of a neglected or abused minor to include "any newborn infant whose blood or urine contains any amount of a controlled substance ... or a metabolite of a controlled substance ...."32 The amended statute facilitates judicial jurisdiction over drug-exposed newborns and their removal from their mothers. ${ }^{33}$ Several other states have amended or enacted laws under which a child who is born drug-dependent or drug-exposed is considered to be abused or neglected. ${ }^{34}$ The Pennsylvania legislature is considering similar legislation. ${ }^{35}$ It has been suggested that "states could promote the unborn's potentiality for life by outlawing fetus endangerment, abandonment, neglect and nonsupport." 36 Such legislation would parallel the protections commonly in place for live-born children. ${ }^{37}$

The Illinois legislature is also considering a criminal law response to drug use by pregnant women: House Bill 2835 would establish a new criminal statute prohibiting "conduct injurious to a newborn." 38 The Bill states in part:

in 1925 to include fathers within its ambit. See id.

${ }^{32}$ ILL. REV. STAT. ch. 37, para. 802-3(c) (1989); see also Logli, supra note 8, at 27 (supporting the proposition that the statute was responsively amended).

33 See Logli, supra note 8 , at 27.

34 See, e.g., Fla. STAT. ANN. \$ 415.503(9)(a)(2) (West Supp. 1990); Haw. REv. STAT. \$ 587-2 (1985); IND. CODE ANN. \& 31-6-4-3.1 (West Supp. 1990); OKLA. STAT. ANN. tit. 10, § 1101(4) (West 1987). See generally Development in the Law, Fetal Drug or Alcohol Addiction Syndrome: A Case of Prenatal Child Abuse?, 25 WILLAMETrE L. REV. 223, 224 \& n.7 (1989) (listing amendments to Oklahoma and Florida child abuse and neglect statutes). For a discussion of state court action in the absence of explicit statutory directives, see $i d$. at 224-29.

${ }^{35}$ See GEN. ASSEMbLY OF PA., SENATE BILl No. 575, \$ 3 (1989) (proposing an expansion of Pennsylvania's definition of child abuse to include a "substance-abused child," defined as "a child who is born with fetal alcohol syndrome, neonatal abstinence syndrome or the systemic presence of a substance listed in ... 'The Controlled Substance, Drug, Device and Cosmetic Act'n).

${ }^{36}$ Parness \& Pritchard, To Be or Not To Be: Protecting the Unborm's Potentiality of Life, 51 U. CIN. L. REv. 257, 270 (1982) (footnotes omitted); see also CAL. PENAL CODE $\S 270$ (West 1988) (making it a misdemeanor for a parent to fail to provide necessities for a minor child, including "a child conceived but not yet born").

${ }^{37}$ See Parness \& Pritchard, supra note 36, at 270 nn.106-09 (citing California child endangerment, abandonment, neglect, and nonsupport statutes).

${ }^{38}$ See Logli, supra note 8, at 27. 
Any woman who is pregnant and without a prescription knowingly or intentionally uses a dangerous drug or a narcotic drug and at the conclusion of her pregnancy delivers a newborn child, and such child shows signs of narcotic or dangerous drug exposure or addiction, or the presence of a narcotic or dangerous drug in the child's blood or urine, commits the offense of conduct injurious to a newborn. ${ }^{39}$

The new crime would be a felony punishable by probation or a prison term of one to three years. ${ }^{40}$ Defenses include a woman's lack of knowledge that she is pregnant, or her rehabilitation and discontinuation of drug use during the first twelve weeks of pregnancy. ${ }^{41}$

The passage of legislation criminalizing certain maternal behavior during pregnancy and imposing liability for the harmful effects of such behavior on children would satisfy the due process requirement that the legislature, rather than the courts, define criminal offenses. Substantively, it appears that such legislation would be constitutional. While the Supreme Court in Roe $v$. Wade ${ }^{42}$ held that a fetus is not a person within the meaning of the fourteenth amendment, it "did not prohibit lawmakers from extending to the unborn the benefits of personhood in other cases." 43 This part of the Roe holding has been strengthened by the Court's opinion in Webster: legislators may now attribute the qualities of legal personhood even to pre-viable fetuses. ${ }^{44}$ States arguably have a compelling interest in promoting the welfare of fetuses from the moment of conception and this interest may support legislation such as that contemplated here. The state's interest, however, must be balanced against women's constitutional right to privacy. ${ }^{45}$

The correction of constitutional defects through legislative responses to the prosecution of pregnant drug users has not been uniform across the nation. Prosecutors continue to employ existing

${ }^{39} I d$.

${ }^{40}$ See id. at 27-28.

41 See id. at 28.

42410 U.S. 113 (1973).

43 Parness \& Pritchard, supra note 36, at 258.

${ }^{44}$ See Webster v. Reproductive Health Servs., 109 S. Ct. 3040, 3057 (1989) (noting that there was no reason "why the State's interest in protecting potential human life should come into existence only at the point of viability, and that there should therefore be a rigid line allowing state regulation after viability but prohibiting it before viability").

${ }^{45}$ See infra notes $64-72$ and accompanying text. 
statutes that facially protect children only after their birth. ${ }^{46}$ It is unlikely that there will be much incentive for more specific legislation in states where prosecutors have obtained convictions. Successful prosecutors may find it unnecessary to support new legislation. ${ }^{47}$ As long as prosecutors continue to apply existing statutes in derogation of the basic principle of statutory construction that requires reliance on legislative intent, the due process requirements of notice and fair warning will be violated.

\section{Requirements of Notice and Fair Warning}

The Keeler court provided a useful discussion of the notice and fair warning concerns that are currently raised by prosecutors' implicit inclusion of fetuses (or babies who suffered lasting injury as fetuses) within the arnbit of child abuse or drug trafficking statutes. The court stated that " $[t]$ he first essential of due process is fair warning of the act which is made punishable as a crime." 48 This requirement of fair warning is rooted in the Constitution's prohibition against legislative enactment of ex post facto laws. ${ }^{49}$ Relying on the Supreme Court's decision in Bouie v. City of Colum$b_{i a}{ }^{50}$ the Keeler court noted that "unforeseeable judicial enlargement" of existing statutes--a situation analogous to enactment of ex post facto laws ${ }^{51}$-violates the due process requirement of fair

46 See, e.g., Hoffman, supra note 2, at 34 (noting that prosecutor Tony Tague "ordered Kimberly Hardy arrested on the same charge prosecutors routinely use against drug dealers: delivering drugs in the amount of less than 50 grams, a felony in Michigan"); id. at 35 (noting that a prosecutor in North Carolina "charged an addicted mother whose newborn had a positive toxicology test with . . . assault with a deadly weapon").

47 Conversely, prosecutors who have failed to convict women who used drugs during pregnancy may successfully urge state legislatures to pass "corrective" legislation. See Logli, supra note 8, at 27.

${ }^{48}$ Keeler v. Superior Court, 2 Cal. 3d 619, 633, 470 P.2d 617, 626, 87 Cal. Rptr. 481,490 (1970). The court further explained:

That the terms of a penal statute creating a new offense must be sufficiently explicit to inform those who are subject to it what conduct on their part will render them liable to its penalties, is a well-recognized requirement, consonant alike with ordinary notions of fair play and the settled rules of law.

Id. (quoting Connally v. General Constr. Co., 269 U.S. 385, 391 (1926)).

${ }^{49}$ See id. at 636,470 P.2d at 626, 87 Cal. Rptr. at 490 (citing U.S. CoNST. art. I, $\S \S 9,10)$.

50378 U.S. 347 (1964).

51 It explained that 
warning, and concluded that the inclusion of fetuses within the state murder statute constituted such an unforeseeable enlargement. ${ }^{52}$

A comparable unforeseeable judicial enlargement of existing laws is the use of drug delivery statutes in the current prosecutions of addicted mothers. These statutes had typically been used against drug dealers; their application to pregnant addicts was novel and unanticipated. Recognizing the connection between novelty and unforeseeability, the Keeler court rejected the prosecutor's interpretation of the murder statute in part because of its novelty. ${ }^{53}$ While innovative approaches to the drug problem were arguably forthcoming in light of the much-discussed national "war on drugs," foreseeable action included the stricter but uncreative enforcement of laws prohibiting drug delivery, possession, and sale, rather than the novel applications of such laws. With regard to the current prosecutions, it has been noted that " $[\mathrm{t}]$ hese drug [delivery] statutes were not intended to apply to fetuses and prenatal behavior and it was not considered a crime to take drugs during pregnancy when these women did that. They could not have known they were committing a crime. ${ }^{54}$

The unforeseeability of a statute's application must be analyzed from the defendant's perspective if the due process requirements of "notice" and "fair warning" are to have any content. ${ }^{55}$ Potential defendants must be warned or put on notice that their behavior may

when an "unforeseeable state-court construction of a criminal statute is applied retroactively to subject a person to criminal liability for past conduct, the effect is to deprive him of due process of law in the sense of fair warning that his contemplated conduct constitutes a crime." ... "Indeed, an unforeseeable judicial enlargement of a criminal statute, applied retroactively, operates precisely like an ex post facto law [which] ... the Constitution forbids."

Keeler, 2 Cal. 3d at 634, 470 P.2d at 626, 87 Cal. Rptr. at 490 (quoting Bouie, 378 U.S. at 354-55).

${ }^{52}$ See id. at 639, 470 P.2d at 630, 87 Cal. Rptr. at 494.

${ }^{53}$ See supra notes 21-22 and accompanying text.

54 Punishing Pregnant Addicts: Debate, Dismay, No Solution, N.Y. Times, Sept. 10, 1989, at E5, col. 5 [hereinafter Punishing Pregnant Addicts] (quoting Kary L. Moss, an attorney with the ACLU Women's Rights Project, New York); see also Logli, supra note 8 , at 24 (acknowledging that manslaughter and drug delivery statutes were not intended to be used in prenatal injury cases). Because of the courts' duty to enforce laws in consonance with legislative intent, it may be argued that an application of a law in derogation of legislative intent is unforeseeable.

55 See, e.g., Keeler, 2 Cal. 3d at 635, 470 P.2d at 627, 87 Cal. Rptr. at 491 (accentuating the importance of evaluating due process rights from the defendant's point of view by asking, "[W]ould the judicial enlargement of section 187 now proposed have been foreseeable to this petitioner?"). 
subject them to criminal liability. A critical method of notice is the reporting of other cases within the jurisdiction. The Keeler court based its decision in part on its finding "no reported decision of the California courts which should have given petitioner notice that the killing of an unborn but viable fetus was prohibited by [the state murder statute]." ${ }^{\text {"56 }}$ Certainly, people do not consult local case reporters before engaging in criminally questionable conduct; ground-breaking cases, however, do generate a great deal of publicity in the popular media. Arguably, pregnant Floridians who use drugs after Jennifer Johnson's conviction are on notice that they may be prosecuted. ${ }^{57}$

At least one defendant, charged with gestational child abuse after giving birth to two premature, cocaine-exposed babies, has questioned the foreseeability of including a fetus within Florida's child abuse statute. She stated: "I don't feel I'm a child abuser. . . . Being in my shoes, you wouldn't look at it like child abuse. I was abusing myself, and something grew inside me. ${ }^{58}$ This argument has been echoed by lawyers who decry the consequences of according women and their fetuses separate, conflicting interests. $^{59}$

\section{B. Fetal Rights v. Women's Rights}

Since the Supreme Court's 1973 decision in Roe v. Wade, ${ }^{60}$ fetal rights have been continuously expanded. ${ }^{61}$ This trend is likely to continue in the wake of Webster $v$. Reproductive Health Services, ${ }^{62}$

${ }^{56} \mathrm{Id}$. at $636,470 \mathrm{P} .2 \mathrm{~d}$ at $628,87 \mathrm{Cal}$. Rptr. at 492 .

57 On January 3, 1990, a Florida woman pleaded nolo contendre to charges of delivering drugs to her fetus via her umbilical cord. See Woman Pleads No Contest in Cocaine Birth, UPI, Jan. 4, 1990, BC Cycle, Regional News, Fla. (LEXIS, Nexis library, UPST90 file).

${ }^{58}$ Linn, supra note 12 , at 34 , col. 4 .

${ }^{59}$ One Boston lawyer has described the prosecution of women for conduct during pregnancy as "preposterous .... It is conceptually splitting a woman in half by" saying that she is not only doing [something harmful] against herself but that she's also [willfully] doing it against another." Sherman, supra note 1, at 28, col. 3 (quoting Nancy Gertner of the law firm of Silvergate, Gertner, Fine \& Good); see also infra notes $64-72$ and accompanying text.

60410 U.S. 113 (1973).

${ }^{61}$ See Note, The Creation of Fetal Rights: Conflicts with Women's Constitutional Rights to Liberty, Privacy, and Equal Protection, 95 YALE L.J. 599, 602-04 (1986) (discussing the erosion of the requirement that a child be born alive in order to be considered an alleged victim under wrongful death statutes and in criminal law generally).

62109 S. Ct. 3040 (1989); see also McNamara, supra note 5, at 1 (noting that according to the ACLU, within three months of the Webster decision at least 10 cases 
which reserved to the states the right to limit abortions based on an asserted state interest in potential life which may be found compelling throughout pregnancy without regard for fetal viability. ${ }^{63}$ Continued expansion of fetal rights engenders concern that women's rights to privacy and self-determination may be compromised. The prosecution of drug-addicted pregnant women raises the additional problem of essentially punishing for "status."

\section{Privacy Interests}

The fundamental right to bear a child ${ }^{64}$ is virtually unregulated by state law. ${ }^{65}$ A pregnant woman certainly may choose to carry her baby to term regardless of fetal defects or ill effects on her own health. It has been argued that states permissibly could impose more regulations on birth in order to promote the interests of the unborn. ${ }^{66}$ States may be unwilling to do so because of constitutional precedent concerning the privacy of personal decisions regarding procreation, marriage, and contraception. ${ }^{67}$ Webster,

of fetal child abuse already had been filed across the country). See generally Bopp \& Coleson, What Does Webster Mean?, 138 U. PA. L. REV. 157 (1989) (arguing that Roe v. Wade is de facto overruled by Webster).

${ }^{63}$ See Webster, 109 S. Ct. at 3057.

64 The fundamental right of all persons, married or single, to choose freely whether or not to conceive or bear children was recognized by the Supreme Court in Eisenstadt v. Baird, 405 U.S. 438, 453-54 (1972) (stating that "[i]f the right of privacy means anything, it is the right of the individual, married or single, to be free from unwarranted governmental intrusion into matters so fundamentally affecting a person as the decision whether to bear or beget a child" (emphasis deleted and footnotes omitted)).

${ }^{65}$ For a discussion of states' general refusal to regulate births, see Parness \& Pritchard, supra note 36, at 286-93. Parness and Pritchard found that "[s]tate laws compelling birth ... are rather scarce" despite the states' constitutional power to "promote the interest of the unborn in attaining the full potential of life." Id. at 287. Similarly, "while state laws prohibiting the birth of one already conceived might be imaginable [and not necessarily unconstitutional] there seem to be no such laws." Id. at 288-89. In sum, "most state laws affecting the birth of the unborn regulate only the circumstances of birth and leave the ultimate decision regarding birth to the prospective parents." Id. at 292.

${ }^{66}$ See id. at 286-88 (noting that "states retain considerable leeway in implementing policies protecting the interests of the unborn" and suggesting, for example, that states may proscribe post-viability abortion, compel the birth of pre-viable fetuses carried by surrogate mothers, compel a woman to undergo a particular form of childbirth, and compel the conception of a child by artificial insemination when the mother is willing but the father is not); see also Note, Rethinking [M]otherhood: Feminist Theory and State Regulation of Pregnancy, 103 HARV. L. REV. 1325, 1326-33 (1990) [hereinafter Rethinking [M]otherhood] (reviewing and analyzing states' efforts to regulate maternal conduct during pregnancy, including judicial intervention in the birthing process).

67 Cf. Parness \& Pritchard. subra note 36. at 286-87 (noting that. desnite such 
with its recognition of the state's interest in fetal welfare from the moment of conception, ${ }^{68}$ and its widening of the states' opportunity to prohibit abortions, may represent a move toward promoting birth. ${ }^{69}$

To what extent does a woman's decision to carry a baby to term affect her exercise of other fundamental rights, such as the right to privacy? It has been argued that "[o]nce she decides to forgo abortion and the state chooses to protect the fetus, the woman loses the liberty to act in ways that would adversely affect the fetus."70 Endorsement of this position could open the floodgates to prosecutions of pregnant women for any activity that might conceivably harm their fetuses, even if such activity could benefit the mother. ${ }^{71}$ The state would effectively create an adversarial relationship between mother and fetus which might threaten a woman's fundamental rights by controlling her behavior during pregnancy. ${ }^{72}$

precedent, states may regulate birth in a variety of ways). The authors opine that "[f]ar too often, states have failed to promote the interests of the unborn by the means available to them." Id.

${ }^{68}$ See Webster, 109 S. Ct. at 3057 (noting that the "[s]tate has compelling interests in ensuring maternal health and in protecting potential human life, and these interests exist "throughout pregnancy." (quoting Thornburgh v. American College of Obstetricians \& Gynecologists, 476 U.S. 747, 828 (1986) (O'Connor, J., dissenting))).

${ }^{69}$ Arguably, however, the interests of the state and the unborn would be better served by encouraging the abortion of certain fetuses, such as those affected by maternal drug use. See Parness \& Pritchard, supre note 36, at 298 (suggesting that, in some cases, "[l]egal protection of the unborn can be achieved by ... promoting the unborn's interest in not being born").

${ }^{70}$ Robertson, Procreative Liberty and the Control of Conception, Pregnancy, and Childbirth, 69 VA. L. REV. 405, 437 (1983).

${ }^{71} \mathrm{~A}$ woman could be held liable for injuring her fetus by taking action for her own benefit no matter how compelling her need to take the potentially injurious action. For example, a Michigan woman lost custody of her baby for more than one year after the child was born with traces of Valium in its system. The mother had taken the Valium prior to delivery in order to ease the pain caused by a car accident. See Paltrow, supra note 6, at 43 (discussing In re J. Jeffrey, No. 99851 (Mich. Ct. App. filed Apr. 9, 1987)). Other behaviors that pose potential risks to fetuses, regardless of maternal benefit, and that could result in a mother's liability include failing to eat nutritious foods, using drugs (prescription, nonprescription, or illegal), smoking, drinking alcoholic beverages, permitting exposure to infectious disease or to workplace hazards, engaging in immoderate exercise or sexual activity, residing at high altitudes for prolonged periods, or using a general anesthetic or labor-inducing drugs. See Note, supra note 61, at 606-07; see also Paltrow, supra note 6, at 42 (noting the fetal hazards posed by radiation exposure during airplane flights and the risk of toxoplasmosis, a disease contracted through contact with cat feces).

72 See Note, supra note 61 , at 600 . It has been further argued that " $[\mathrm{b}] \mathrm{y}$ substituting its judgment for that of the woman, the state deprives women of their 
Maternal behaviors that may cause fetal harm may be distinguished on a number of bases, such as the magnitude of the risk of harm, the likely severity of the harm, the potential benefits to the mother, and the likelihood that these benefits will be achieved. The distinction most frequently noted, however-that between legal and illegal maternal activity ${ }^{73}$-bears no relation to fetal harm, the danger ostensibly sought to be avoided by prosecuting pregnant drug users. ${ }^{74}$ Further, it is axiomatic that illegal acts are illegal regardless of the actor's reproductive status, so that pregnant women who commit drug-related crimes are already subject to prosecution regardless of their pregnancies. The legal-illegal distinction is particularly problematic in the context of prosecuting addicts.

\section{A New Status Crime?}

Drug addiction has been judicially designated a status, which cannot be penalized as such. The Supreme Court in Robinson $v$. Califormia ${ }^{75}$ held unconstitutional a state law that criminalized the condition of being a drug addict and accepted the validity of a disease model of drug addiction. ${ }^{76}$ At least a portion of the medical community currently regards substance abuse as a disorder warranting medical intervention and treatment. ${ }^{77}$ Recent prosecu-

right to control their lives during pregnancy-a right to liberty and privacy protected by the Constitution. Furthermore, by regulating women as if their lives were defined solely by their reproductive capacity, the state perpetuates a system of sex discrimination that is based on the biological difference between the sexes, thus depriving women of their constitutional right to the equal protection of the laws." Id. at 613; see also Relhinking [M]otherhood, supra note 66, at 1333-42 (criticizing the rights-based construction of mother and fetus as adversaries, particularly in the context of maternal substance abuse, and emphasizing instead the intimate connection between mothers and their fetuses).

${ }^{73}$ See infia note 149.

${ }^{74}$ See supra note 71 and accompanying text (describing legal maternal behaviors that may harm fetuses); see also infra notes 146-53 and accompanying text (discussing the overall failure to prosecute women whose prenatal smoking or drinking injures their fetuses).

75370 U.S. 660,667 (1962).

${ }^{76}$ The Court explained that narcotic addiction "is apparently an illness which may be contracted innocently or involuntarily. ... [and] that persons addicted to narcotics "are diseased and proper subjects for [medical] treatment." Id. at 667 \& n.8 (quoting Linder v. United States, 268 U.S. 5, 18 (1925)).

${ }^{77}$ For example, the DIAGNOSTIC AND STATISTICAL MANUAL OF MENTAL DISORDERS (rev. 3d ed. 1987) [hereinafter DSM-III-R] published by the American Psychiatric Association describes substance use disorders, including alcoholism and cocaine abuse. See id. at 165-85. 
tions of women who were pregnant drug addicts have been criticized for essentially punishing a status, or the coexistence of two statuses that alone would be unpunishable and undeserving of punishment. As determined by Robinson, the status of being a drug addict cannot constitute a crime. Even drug use, a symptom of addiction, is not ordinarily a crime. ${ }^{78}$ If drug addiction or drug use is not a crime, "then what is being punished [by these prosecutions] is the status of being pregnant ${ }^{m 79}$ when it coexists with the status of drug addiction or with drug use. The result of criminalizing the coexistence of two unpunishable statuses-drug addiction and pregnancy--is the creation of a new status crime. ${ }^{80}$ The harm to others, such as the babies of drug addicts, which may result from the convergence of addiction and pregnancy may be addressed by independent statutes that focus on harm, not status. ${ }^{81}$ Indeed, it is typically the case that when drug or alcohol use results in harm to another person, the harmful "undesirable behavior is ordinarily proscribed by another criminal statute . . . the prosecution is limited to the crime ... independent of drug use." 82 If drug use alone is not a crime, but drug use by pregnant women is, then pregnancy constitutes "a necessary element of a remarkable new status-based criminal offense: [p]regnancy by a drug-dependent person, or drug use by a pregnant woman." 83

The recent expansion of fetal rights, as demonstrated by prosecutions of pregnant drug addicts, may effectively deny the fundamental right of reproduction to a particular class of sick women (drug addicts) whose symptoms (compulsive drug use) may injure their fetuses. This emphasis on fetal rights may lead to further incursions on the rights of ill women to bear children. There can be no justification for imposing criminal sanctions on diseased persons simply because they are sick. The question becomes whether the fact that a person is ill may be used as the

${ }^{78}$ See Mariner, Glantz \& Annas, Pregnancy, Drugs and the Perils of Prosecution, 9 CRIM. JUST. ETHICS 30, 31 (1990).

79 Id.

${ }^{80}$ See id.; Paltrow, supra note 6, at 41-42.

${ }^{81}$ See Mariner, Glantz \& Annas, supra note 78, at 31; see also infra notes $95-99$ and accompanying text (discussing the legal infirmities of prosecuting pregnant addicts in light of the need to show intent).

${ }^{82}$ Mariner, Glantz \& Annas, supra note 78, at 31.

${ }^{83} \mathrm{Id}$; see also Paltrow, supra note 6, at 41-42 (stating that "none of the women have been arrested for the crime of illegal drug use or possession. Instead, they are being arrested for a new and independent crime: becoming pregnant while addicted to drugs."). 
basis for regulating that person's behavior to the point of circumscribing rights that she would be accorded if she were healthy. From the perspective of furthering fetal and childhood well-being, it is clearly not in the best interests of children to be born of women who are HIV-positive, cancer patients, or alcoholics. Alcoholic women, women who are infected with HIV, and women who refuse medical treatment for pregnancy-related ailments place their fetuses at an increased risk of illness and physical and developmental abnormalities. ${ }^{84}$ Pregnant women who have cancer or epilepsy often require drugs that may harm their fetuses. ${ }^{85}$ The constitutional protections that preserve such persons' right to procreate should extend to substance abusers as well. Adults have a right to procreate, while children have no corollary right to be born healthy, financially secure, or into a two-parent family. ${ }^{86}$ In each of these cases the potential parent's right to reproduce predominates over any imagined right of the fetus to be born to a healthy mother. The prosecutions of drug-addicted mothers could foreseeably lead to procreation being considered a privilege to be granted by the state rather than a right rooted in the Constitution.

\section{CRIMinal Theory}

The current prosecutions of pregnant drug users demonstrate a disregard for commonly accepted theories and objectives of the criminal law. This Comment will examine two aspects of this problem. First, the general prohibition against punishing persons for their involuntary behavior will be considered in light of the nature of drug addiction and the attendant potential for deterrence. Second, Professor Kadish's criminogenesis analysis will be applied to the current prosecutions. It will be argued that these prosecutions create more harm than good.

84 See Nolan, Protecting Fetuses from Prenatal Hazards: Whose Crimes? What Punishment?, 9 CRIM. JUST. ETHICs 13, 15 (1990).

${ }^{85}$ See Paltrow, supra note 6, at 42.

${ }^{86}$ George J. Annas, professor of health law at Boston University School of Medicine, comments: "There is no question women have the constitutional right to become pregnant and give birth. Are we willing to sterilize everyone who has a disease that can be passed to a fetus?" Punishing Pregnant Addicts, supra note 54, at E5, col. 6 .

Commenting on the wave of prosecutions of women who use illegal drugs during pregnancy, social critic P.J. O'Rourke cynically noted, "If the legal reasoning belind these cases is sound, then we should all go out and get our mothers arrested for failing to marry rich guys with speedboats and big trust funds." O'Rourke, 1989-Slime Time Live, Rolling Stone, Dec. 14-28, 1989, at 36, 43. 


\section{A. Punishing Involuntary Behavior}

The Anglo-American criminal law tradition has consistently recognized the immorality and futility of punishing individuals for involuntary behavior. Culpability generally requires a voluntary act; people do not deserve punishment for acts they neither intended nor controlled. The Model Penal Code (MPC), for example, imposes no criminal liability in the absence of a voluntary act or omission. ${ }^{87}$ The voluntary act requirement exists, among other reasons, to foster deterrence, a primary goal of the criminal law. ${ }^{88}$ Distinguishing between voluntary and involuntary acts has proved difficult, and behavior associated with drug addiction presents unique problems of classification. This section will describe involuntary aspects of drug addiction and analyze the problems associated with punishing addicts for the consequences of their involuntary acts.

The Supreme Court has long recognized that drug addiction is an illness, stating that addicts "are diseased and proper subjects for [medical] treatment. ${ }^{n 9}$ The disease model of addiction is widely accepted by the medical community, ${ }^{90}$ and the American Psychiatric Association categorizes substance-use disorders as mental disorders. ${ }^{91}$ These disorders, including the cocaine dependence plaguing many mother-defendants, are addictions, identified in part by the diagnostic criterion of "continued use despite knowledge of having a persistent or recurrent ... problem that is caused or exacerbated by the use of the ... substance." 92 This loss of control over drug intake may be particularly pronounced in crack users. "The drug's hold is so vicious, so absolute, that it overrides even the most basic of human drives. .. . [This] is why a woman can keep getting high while she's pregnant, or interrupt the delivery of

${ }^{87}$ See MODEL PENAL CODE $\S 9.01(1)$ (1962) (“A person is not guilty of an offense unless his liability is based on conduct that includes a voluntary act or the omission to perform an act of which he is physically capable."). Drug-taking is an act, not an omission; the discussion in this Comment will be restricted, therefore, to voluntary and involuntary acts, rather than to omissions.

${ }^{88}$ See id. \$ 2.01 comment I ("[T]he law cannot hope to deter involuntary movement or to stimulate action that cannot physically be performed . . . .").

${ }^{89}$ Linder v. United States, 268 U.S. 5, 18 (1925).

${ }^{90}$ See, e.g., Smith, Substance Use Disorders: Drugs $\mathcal{E}^{\circ}$ Alcohol, in REviEw OF GENERAL PSYCHIATRY 278, 279 (H. Goldman ed. 1984) (describing the World Health Organization's definition of addiction).

${ }_{91}$ See DSM-III-R, supra note 77, at 165-85.

92 Id. at 169. 
twins to call her dealer, or forget that she delivered a baby altogether." ${ }^{93}$ Such addictive behavior may be considered compulsive or irresistible. Women who want to take proper care of their children, during pregnancy and after, find themselves unable to do so because of the overpowering effect of drugs. ${ }^{94}$

Punishing involuntary, addictive behavior is unlikely to deter that behavior, because the actor is unable to control her behavior. Nonetheless, courts have been unwilling to excuse liability for acts resulting from irresistible impulses. ${ }^{95}$ Punishment is often justified on the basis of protecting third parties from harm caused by substance abusers' uncontrollable acts. ${ }^{96}$

The risk-to-others analysis is unsatisfactory in the pregnancy context because it is unlikely that pregnant addicts are culpable within the accepted terms of criminal law. ${ }^{97}$ A woman who does

99 Linn, supra note 12, at 26.

94 Charles Hux, director of maternal/fetal medicine at Hahnemann University Hospital in Philadelphia has stated:

[T] he monster in all this is cocaine .... A lot of women ... would like to be good human beings and would like to live the right lifestyle. But the cocaine makes a monster out of them .... You have to hate the drug and not hate the mom. You have to look at what the drug does to human beings.

Id.

95 The definition of an involuntary act has been explained as follows:

[I]n the criminal law an act is not to be regarded as an involuntary act simply because the doer does not remember it. . . . Nor is an act to be regarded as an involuntary act simply because the doer could not control his impulse to do it. ... Nor is an act to be regarded as an involuntary act simply because it is unintentional or its consequences are unforeseen.

S. KADISH, S. SCHULHOFER \& M. PAULSEN, supra note 23, at 253; see also Powell v. Texas, 392 U.S. 514, 521 (1968) (refusing to recognize chronic alcoholism as a defense to a charge of appearing drunk in public despite the prevailing medical view that "a chronic alcoholic does not appear in public by his own volition but under a compulsion symptomatic of the disease of chronic alcoholism").

${ }_{96}^{6}$ See supra notes $81-82$ and accompanying text. Jeff Deen, the Florida prosecutor who initiated proceedings against Jennifer Johnson, stated that one policy goal of such prosecutions is "to interrupt the cycle, so we don't end up with another cocaine baby." Linn, supra note 12, at 25. In addition, it is hoped that punishment may prevent convicted addicts from repeating injurious behavior by incapacitating them through imprisonment. It is important to note, however, that even the incarceration of pregnant drug users cannot guarantee that they do not use drugs, as noted by Dr. Brian Udell of Broward General Medical Center, who "had two patients who were smoking coke in jail on the day of their delivery." Id. at 26; see also Nolan, supra note 84 , at 19 (stating that "[d]rug use can continue despite imprisonment, and medical attention for pregnant women in prisons may be sorely inadequate").

${ }^{97}$ See MODEL PENAL CODE $\$ 2.02(1)$ (1962) (describing the culpability requirement that the defendant must have acted purposely, knowingly, recklessly, or negligently). 
not know that she is pregnant clearly must be unaware that her drug use is injuring anyone but herself. This case is clearly distinguishable from that of the drunk driver who knows or should know that other cars have access to the road, or the crack addict who forms and carries out the intent to rob while under the influence of drugs. Moreover, an addict who knows she is pregnant may be unaware of the drug's effects on her fetus. When a pregnant addict takes drugs, she often will not view the fetus as a victim, and she probably intends no harm to the baby at all. ${ }^{98}$ It may be difficult even to prove that drug-taking during pregnancy is reckless. To have successfully convicted Melanie Green of involuntary manslaughter, prosecutor Logli would have to have proved that she acted recklessly in taking drugs when pregnant-that she took a risk that a reasonable person would not have taken. The grand jury determined that Logli had not proved this mens rea requirement of the offense. ${ }^{99}$

Conceptually, pregnant addicts may be likened to the "temporarily insane" who successfully defend against criminal charges on the grounds of lack of culpability. It must be noted, however, that defendants who have committed criminal acts under the influence of drugs have been unsuccessful in arguing that drugs produced temporary insanity that should excuse their behavior. ${ }^{100}$ This defense is typically rejected on the ground that the drugs were taken voluntarily with knowledge of the likely effects on behavior. ${ }^{101}$ It is, however, possible that this argument may be applied with greater success in the context of the prosecutions at issue here.

Although the pathogenesis of crack addiction may consist of initial voluntary drug use, falling within the MPC's definition of self-

${ }^{98}$ See supra notes 58-59 \& 93-94 and accompanying text. James Bopp, general counsel to the National Right to Life Committee, believes that prosecutions of pregnant drug users are flawed because it is nearly impossible to prove that the women intended to injure their babies. He stated that such prosecutions "are rarely justified because it must be proven that a woman knowingly intended to pose substantial risk of harm to the unborn child. It's unlikely a woman takes drugs to harm her child. Cocaine addiction is compulsive behavior." Punishing Pregnant Addicts, supra note 54, at E5, col. 6 .

${ }^{99}$ See Reardon, Drugs and Pregnancy Debate Far From Resolved, Chicago Tribune, May 28, 1989, at 5, col. 1. See generally Mariner, Glantz \& Annas, supra note 78, at 35-36 (discussing criminal intent in the context of drug use by pregnant women).

100 See, e.g., State v. Hall, 214 N.W.2d 205 (Iowa 1974) (rejecting defense of temporary drug-induced insanity by defendant who committed murder under the influence of LSD).

101 See id. at 208; see also MODEL PENAL CODE § 2.08(5) (1962) (defining selfinduced intoxication, which is not a defense). 
induced intoxication, ${ }^{102}$ this stage is often followed by involuntary drug use. ${ }^{103}$ Once a person is addicted, she may be considered to have a "mental disease" within the terms of the MPC. ${ }^{104}$ If a woman becomes pregnant after she is addicted and when her drug use has become involuntary, it can be argued that drug-induced temporary insanity prevented her from recognizing or considering the likely ill effects of the drug on her fetus. Indeed, addicts' descriptions of the effects of crack can be deemed consistent with temporary insanity. ${ }^{105}$ Even when a pregnant addict knows that crack is injurious to her fetus, the insanity-like effects of the drug may render her unable to act in accordance with this knowledge. ${ }^{106}$

\section{B. Criminogenesis}

In the late 1960s, some lawyers attempted to limit the scope of the criminal law by analyzing the effects of laws on the overall functioning of the criminal justice system. ${ }^{107}$ According to Professor Kadish, the enforcement of certain laws has a criminogenic effect: enforcement breeds more harm than ignoring the offenses. Kadish concluded that three classes of offenses should be abolished because of their criminogenic effects. These categories are morals offenses, offenses that serve to permit police or prosecutorial intervention into what is more properly the realm of social service agencies, and offenses that manufacture police authority to apprehend suspected criminals with slight cause. ${ }^{108}$ Although these offenses have been characterized as "private" or

102 See MODEL PENAL CODE $\$ 2.08(5)$ (1962).

103 See DSM-III-R, supra note 77, at 165 (noting that involuntary drug use-the inability to cut down or discontinue use-is one indication of a pattern of pathological use that is distinguishable from nonpathological psychoactive substance use).

${ }^{104}$ Under the Model Penal Code, intoxication alone is not evidence of a mental disease. See MODEL PENAL CODE $\S 2.08(3)$ (1962). A bona fide mental disease, however, may constitute a defense to criminal charges. See id. \$ 4.01(1) ("A person is not responsible for criminal conduct if at the time of such conduct as a result of mental disease or defect he lacks substantial capacity either to appreciate the criminality [wrongfulness] of his conduct or to conform his conduct to the requirements of the law.").

${ }^{105}$ Cf. Linn, supra note 12 , at 26 (stating that crack cocaine's strong hold on the addict undermines the maternal instinct).

106 See supra notes 93-94 and accompanying text.

107 See Kadish, The Crisis of Overcriminalization, 374 ANNALS 157 (1967); Kadish, More on Overcriminalization: A Reply to Professor Junker, 19 UCLA L. REV. 719, 719-20 (1972) [hereinafter Kadish, More on Overcriminalization].

${ }^{108}$ See Kadish, The Crisis of Overcriminalization, supra note 107, at 157, 159. 
"victimless" crimes, ${ }^{109}$ ternns inapplicable to drug-abuse by pregnant women whose babies are considered victims, the prosecution of these women may be viewed as an attempt by the criminal justice system to provide services such as drug counseling or medical care in the face of default by social service agencies. ${ }^{110}$

Kadish's analytical framework is well suited to these prosecutions. He considers "how the inevitable process of actual enforcement of ... laws (a) so poorly serves the objectives [of enforcement], and (b) in any event produces a variety of substantial costs, including adverse consequences for the effective enforcement of the criminal law generally."111 This two-step analysis requires a determination of the legal objectives in question and a weighing of the costs and benefits of enforcement. The objectives of prosecuting women who deliver drug-exposed babies have been identified as deterring prosecuted women from having more drug-exposed children, ${ }^{112}$ and providing drug counseling or other care. ${ }^{113}$ Kadish identifies four types of enforcement costs that may outweigh the benefits of enforcing laws that poorly serve their asserted objectives: (1) diminished respect for law; (2) unenforceability, corruption, and discrimination; (3) the crime tariff; and (4) misallocation of enforcement resources. ${ }^{114}$

${ }^{109}$ Junker, Criminalization and Criminogenesis, 19 UCLA L. REv. 697, 698 (1972).

${ }_{110}$ Prosecutor Jeff Deen argies that the purpose of these prosecutions is to get drug-addicted mothers into trealment programs, not to punish them. See Linn, supra note 12 , at 25,34 . Jennifer Johnson, who was prosecuted by Deen, is serving a sentence that includes mandatory drug treatment. See id. at 34 . Unfortunatcly, pregnant drug addicts may find that conviction is their only certain path to drug treatment. Many poor, pregnant women are unable to get drug treatment without judicial intervention because they are routinely excluded from treatment programs. For example, a survey of 78 drug treatment programs in New York City found that $54 \%$ excluded pregnant women, $67 \%$ excluded pregnant Medicaid recipients, and $87 \%$ excluded pregnant crack addicts on Medicaid. See Sherman, supra note 1, at 29, col. 2. Melanie Green sought drug treatment but was confronted by six-montl waiting lists. See McNamara, supra note 5 , at 11 , col. 3. Such waiting periods are particularly problematic for pregnant women, who may be unable to enter treatment until after considerable harm has been done to their fetuses. See also One Drug-Using Mother's Story, 11 YOUTH L. NEwS 19 (1990) (describing a pregnant heroin addict's attempts to obtain treatment, her loss of child custody, and her possible prosecution).

11 Kadish, More on Overcriminalization, supra note 107 , at 720 .

112 See Linn, supra note 12, at 25.

${ }^{113}$ See supra note 110; see also Punishing Pregnant Addicts, supra note 54, at E5, cols. 2-3 "The nice thing about jail is that moms get good prenatal care, good nutrition and they're clean." (quoting Dir. Jan Bays, Director of Child Abuse Programs, Emanuel Hospital, Portland, Or.)). But see supra note 96 (noting the possible availability of drugs and the inadequacies of prenatal care in prisons).

${ }^{114}$ See Junker, supra note 109, at 700; Kadish, The Crisis of Overcriminalization, 
This section will argue that these prosecutions do not fulfill their objectives, and that the costs of enforcing sanctions against drug-using mothers outweigh the benefits. Costs incurred in categories (1), (2) and (4) will be discussed. Category (3) is inapplicable because it is identified as a special cost of using the criminal law "to prohibit commercial transactions in goods and services." 115

\section{Objectives of the Prosecutions}

The asserted and implicit objectives of the prosecutions have been discussed above. Briefly, prosecutors hope to deter pregnant women from taking drugs and drug addicts from having children. While general deterrence may be unachievable because of the involuntary nature of drug use by addicts, incapacitation and specific deterrence are hailed as viable goals to be attained by the incarceration or monitoring of pregnant addicts. Prosecuted addicts may be sentenced to attend rehabilitation programs to which they may have been denied admission previously.

It is too early to tell what the long-term effects of these prosecutions will be on the mothers and children involved. For children born of drug addicts, the intervention wrought by prosecuting their mothers may prove futile. The children will suffer the long-term effects of their mothers' drug use regardless of medical, legal, or social intervention. ${ }^{116}$ If the mothers prove unable to care for their children adequately, the legal system may resort to proceedings to determine maternal fitness regardless of drug-addiction status. The alleged benefits of the prosecutions discussed in this Comment may accrue to the as-yet unconceived babies of addicts and former addicts.

Florida prosecutor Jeff Deen asserted that the goal of prosecuting women who deliver drug-exposed babies is to deter them from

supra note 107 , at $160,163-64$.

115 Junker, supra note 109 , at 707. Crime tariff costs may militate in favor of decriminalizing narcotics. See Kadish, The Crisis of Overcriminalization, supra note 107, at 163-65; see also infra note 149 (discussing renewed debate concerning drug legalization). The illegality of substances used by pregnant women is not at issuc here, however. See infra text accompanying notes, 148-52. The other elements of the cost-benefit analysis $(1,2,4)$ apply to the prosecutions in question here as well as to the potential extension of prosecutions to pregnant users of alcohol and tobacco.

${ }^{116}$ See Lockwood, What's Known-And What's Not Known-About Drug-Exposed Infanis, 11 YouTH L. News 15 (1990); Morrow, Early Intervention Prograins May Help DiugExposed Children, 11 YouTH L. NEws 31 (1990). 
having more afflicted children. ${ }^{117}$ The attainment of this goal, however, turns on the deterrent function of these prosecutions. The nature of addiction makes it unlikely that these prosecutions will have much deterrent value. ${ }^{118}$ In addition, the goal of insuring fetal health may better be served by providing pregnant addicts with drug treatment and prenatal care. It may be that the only goal served by these prosecutions is punishment, an objective denied by prosecutors. ${ }^{119}$ Thus, uncler the first prong of Kadish's analysis, the enforcement of sanctions against women who deliver drugexposed babies poorly serves the objectives of enforcement.

\section{Loss of Respect}

Whether these prosecutions engender a loss or gain of respect for the criminal justice system depends upon the sociopolitical views of the speaker. Some see the prosecutions as creative approaches to a seemingly insoluble problem. ${ }^{120}$ Prosecutors may be viewed as "making a difference," reducing the drug problem to individual terms, and vindicating the rights of innocent child-victims. Others, however, feel that prosecutors have misused their power and authority, terrorizing poor women who lead desperate lives rather than prosecuting those who make drugs available in the first place. ${ }^{121}$ The failure of the Winnebago County grand jury to

117 See Linn, supra note 12 , at 25.

118 See supra notes $92-96$ and accompanying text.

119 See Mariner, Glantz \& Annas, supra note 78, at 37.

120 For example, Dr. Jan Bays, Director of child abuse programs at Emanuel Hospital in Portland, Oregon, has stated:

We must up the ante to criminalize or impose reproductive controls on people who are out of control . . . . I'm fed up with seeing damaged babies born who have lost the right to make what they can out of life .... I don't see that the courts have had any impact.

We thought we were getting tough when we tried voluntary contracts that required the parents to go into drug treatment, gave the state legal custody or allowed it to monitor the child. But it doesn't work .... We can't say forever that people have unlimited rights to have a child.

Punishing Pregnant Addicts, supra note 54, at E5, col. 2-3.

Plymouth County, Massachusetts Prosecutor William C. O'Malley has said, "I'd much rather see this problem dealt with by the more subtle systems of public health, social services and education. Bul., damn it, we've had nothing but failures . . . . It's time to invoke the mechanism of last resort." Id. at E5, col. 4.

121 Neonatologist Dr. Loretta Finnegan, founder of a program for pregnant addicts in Philadelphia, notes that most of the women she treats have been the victims of childhood sexual or physical abuse, rape as adolescents, and domestic violence at the hands of husbands or boyfriends as adults. See Linn, supra note 12, at 25; see also Paltrow, supra note 6 , at 42 (noting that several recently prosecuted women have been 
indict Melanie Green has been construed as a victory of compassion and common sense over prosecutorial gamesmanship. ${ }^{122}$ At the very least, these prosecutions send a message about the new willingness of government to interfere in the most intimate aspects of women's lives. It may be increasingly difficult to maintain respect for a system that prosecutes drug-addicted mothers, arguably the victims of profit-seeking drug dealers, while the dealers are perceived as "going free."

\section{Unenforceability}

The enforcement of criminal sanctions against women who deliver drug-exposed babies raises serious concerns about the proper role of the medical profession in identifying defendants. Currently, some states require medical professionals to report the drug-dependence of newborns or the presence of drugs in their systems. ${ }^{123}$

Many medical professionals are uncomfortable about being forced to set these prosecutions in motion. ${ }^{124}$ Some health care providers believe that potential liability will discourage pregnant drug addicts from seeking prenatal care. ${ }^{125}$ "Health care providers fear that they will lose the struggle to bring pregnant women into prenatal care and that mothers will not deliver their babies in hospitals. They foresee more abandoned babies, more seriously disabled babies, more infant deaths. ${ }^{\text {126 }}$ Some women whose

battered); $i d$. at 45 (noting that many drug-addicted women were victims of rape or incest).

George J. Annas argues that "[t]o prosecute people who make money off drugs can be useful. But to drag in pregnant women is not, because they have real problems [in addition to] drugs. Usually it's poverty, discrimination, living where services aren't available." Punishing Pregnant Addicts, supra note 54, at E5, col. 6.

122 See Colen, Reining in Runaway Prosecutors, Newsday, June 6, 1989, at 13 (Nassau \& Suffolk ed.).

123 See, e.g., D.C. CODE ANN. § 2-1352 (Supp. 1990); FLA. STAT. ANN. $\S \S 415.503(9)(\mathrm{a})(2), 415.504$ (West 1986 \& Supp. 1990); HAW. REV. STAT. \$§ 3501.1(a), 587-2 (1985 \& Supp. 1989); ILL. ANN. STAT. ch. 23, para. 2053, 2054 (SmithHurd 1988 \& Supp. 1990); MASS. ANN. LAWS ch. 119 § 51A (Law. Co-op. 1990); N.Y. SOc. SERV. LAW § 412(9) (McKinney Supp. 1990); OKLA. STAT. ANN. tit. 21, § 846A (West Supp. 1989).

${ }^{124}$ See Pinkney, Drugs in Pregnancy: A Growing Crisis With no Easy Solution, Am. Med. News, Oct. 6, 1989, at 30, col. 4 (discussing pressures on the medical community to identify women who use drugs during their pregnancies).

$125 \mathrm{See} i d$. at 1 , col. 4 (noting a warning that a "punitive atmospliere against cocaine users threatens to drive women out of the health care system and to taint efforts to deal with addiction as a medical problem"); Linn, supra note 12, at 24.

126 Larsen, Creating Common Goals for Medical Legal and Child Proteclion 
babies test positive for drugs may be enrolled in substance abuse programs or may voluntarily seek treatment with the help of supportive families; ${ }^{127}$ medical professionals may deem criminal intervention in such cases to be inappropriate. ${ }^{128}$ Prenatal drug treatment is very difficult to obtain ${ }^{129}$ and many medical professionals believe that rather than being penalized, women who are successful in locating such care should be rewarded and encouraged to take care of themselves and their babies. These considerations may make health care providers resist compliance with reporting requirements, and such resistance could render criminal sanctions unenforceable.

Attempts to evade reporting requirements may also have criminogenic effects. As Kadish states, the creation of a new category of crime is likely to breed an increase in other related crimes. ${ }^{130}$ For example, medical personnel may refuse to reveal their drug findings in an effort not to lose their patients, or potential defendants may attempt to bribe hospital staff to suppress their reports. ${ }^{131}$ Furthermore, demand for abortions may also increase, ${ }^{132}$ and if states continue to limit the legal availability of abortions, this increased demand will be for illegal procedures.

\section{Corruption and Discrimination}

Corrupt or discriminatory enforcement of sanctions lessens respect for the law and may generate more crime. For example, women who are likely to be prosecuted may bribe officials, while those unlikely to face charges engage in criminal behavior unde-

Communities, in A.B.A CENTER ON CHILDREN AND THE LAW, DRUG EXPOSED INFANTS AND THEIR FAMILIES: COORDINATING RESPONSES OF THE LEGAL, MEDICAL AND CHILD PROTECTION SYSTEM 3, 6 (1990).

127 See id.

128 See id.

${ }^{129}$ See Chavkin, supra note 14, at A21, col. 2 (discussing surveys of the availability of prenatal programs for pregnant addicts); see also Sherman, supra note 1, at 29, col. $1-2 ;$ supra note 110 and accompanying text.

${ }^{130}$ See Kadish, The Crisis of Overcriminalization, supra note 107 , at 164 (finding that the criminalization of gambling and selling narcotics has spawned organizations that engage in "satellite forms of crime" such as bribery, loan-sharking, and labor racketeering).

${ }^{131}$ Dishonesty on the part of a potential defendant has already been noted. Lynn Bremer has acknowledged that she brought another person's drug-free urine samplc to her doctor for testing, claiming that the sample was her own. See Hoffman, supra note 2 , at 55 , col. 2 .

${ }^{132}$ See Paltrow, supra note 6, at 42. 
terred. Discriminatory enforcement of the reporting requirement-the preliminary stage in the prosecution of pregnant drug users-has already been reported in Pinellas County, Florida. ${ }^{133}$ A study found that black mothers were 9.58 times more likely to be reported for their substance abuse even though white women were 1.09 times more likely to have abused a substance just prior to their first prenatal care visit. ${ }^{134}$ This pattern is consistent with the notion that the real motivating factor behind these prosecutions is drug hysteria, aimed specifically at poor, minority addicts who are often viewed as causes of the drug problem rather than its victims. ${ }^{135}$ More than half of the women who have been prosecuted thus far are women of color. ${ }^{136}$ As crack spreads beyond the inner city and gains a hold in suburbia, ${ }^{137}$ there will be more middle- and upper-class white addicts. It remains to be seen whether they will face prosecution as frequently as their poorer black and white counterparts. ${ }^{138}$

The prosecutions at issue poorly serve the goals asserted by prosecutors. In addition, substantial harms to the criminal justice system are introduced: people may lose respect for the system, lack of compliance by medical personnel may render the foundation reporting statutes unenforceable, and corruption and discrimination may ensue as women and their health care providers seek to avoid criminal intervention and as the judicial system disproportionately sanctions poor, minority women. Thus, under Kadish's analysis, this prosecu, orial approach should be abandoned in favor of intervention by medical and social service agencies.

133 See Sherman, supra note 1, at 28-29, col. 4.

${ }^{134}$ See id.

135 It has been noted that "[o]ur society has a history of discrimination against women, blacks and poor people. The majority of those being denied drug treatment and then being arrested in these cases are all three." McNamara, supra note 5, at 11, col. 3 (quoting ACLU attorney Lynn Paltrow); see also Linn, supra note 12, at 24; Paltrow, supra note 6, at 42.

${ }^{136}$ See Paltrow, supra note 6, at 42.

${ }^{137}$ See Malcolm, Crack, Bane of Inner City, is now Gripping Suburbs, N.Y. Times, Oct. $1,1989, \S 1$, at 1 , col. 1 (reporting substantial increases of crack addiction among white upper-income and middle-income Americans).

${ }^{138}$ One prosecution has been brought against a white, middle-class cocaine addict. See Hoffman, supra note 2, at 35, col. 2 (discussing the prosecution in Michigan of attorney Lynn Bremer). 


\section{Protecting Life or Combatting Drug Abuse?}

Prosecutions of women who deliver drug-exposed babies may also be seen as an expression of national concern about two major social issues: abortion ${ }^{139}$ and drug abuse. ${ }^{140}$ It appears to be more than coincidence that the rash of these prosecutions during the summer of 1989 followed the Webster decision and accompanied a heightened public focus on abortion and the "war on drugs." At first glance, these prosecutions appear perfectly consistent with "right to life" policies and objectives, such as the promotion of birth and the acknowledgement of fetal rights. Further analysis, however, reveals that such prosecutions actually may lead to consequences that ardent supporters of fetal rights would not condone. Pregnant drug addicts may be less likely to seek medical care that could benefit their unborn children and themselves, or they may seek abortions.

Many health care providers have expressed concern about the chilling effect that these prosecutions are likely to have on pregnant drug addicts' seeking medical attention. ${ }^{141}$ They believe that

139 See McNamara, supra note 5, at 1, col. 2-3 ("It is foolish to think these suits aren't related to the abortion issue .... They spring from the same concern that drives the antiabortion position--that is to say, assigning a more elevated moral and legal status to the fetus, granting it personhood separate from the woman carrying it." (quoting Arthur Caplan, professor of ethics, University of Minnesota)); Punisling Pregnant Addicts, supra note 54, at E5, col. 6 ("This is a surrogate for the big debate on abortion. Although pro-choicers are sympathetic to prenatal issues, they are terrified to give in at all on fetal rights for fear of providing grist to anti-abortionists." (quoting Alan Dershowitz)).

${ }_{140}$ See Hoffman, supra note 2, at 57 (stating that "[t]his crusade is not about getting women into treatment or protecting babies ... [but] about winning the war on drugs." (quoting Alan Rapoport, one of Kimberly Hardy's attorneys)); Logli, supra note 8 , at 23 .

${ }^{141}$ See Linn, supra note 12, a.t 24; Pinkney, supra note 124, at 1, col. 4. But see supra note 120 (concerning a doctor's advocacy of the use of criminal sanctions against mothers who bear drug-affected babies).

Attorneys and defendants have also expressed concern about the consequences of candid discussion with health care professionals-consequences that, if foreseen by other pregnant addicts, may deter them from seeking prenatal care.

Jennifer Johnson's attorney has noted the legal significance of his client's discussion of her addiction with medical personnel:

The interview [with the hospital's social worker] became the backbone of the prosecution's case .... [A]fter a while, she was also interviewed by a police investigator . . . and she talked with him and he discussed if she used cocaine while she was pregnant. She said yes. She didn't anticipate that this was going to lead to an arrest. She thought this is what she had to do to get the child back.

Linn, supra note 12, at 25. 
incentives should be structured to encourage these women to seek prenatal care, which may include drug counseling, rather than avoid it because of fear of prosecution. Supporters of fetal rights, who envision a fetal right to a drug-free, healthy gestation, ${ }^{142}$ must recognize that this goal can be accomplished more fully by encouraging drug addicts to seek medical care than by threatening them with criminal sanctions. ${ }^{143}$ The women who have been prosecuted to date had already delivered drug-exposed babies when they were charged with criminal offenses. It is obvious that both these women and their babies would have enjoyed a healthier pregnancy had their drug abuse been detected and treated as early as possible. Their prosecutions send a message to others in their position that an attempt to find proper medical care during pregnancy will lead to criminal court.

It also is likely that some pregnant addicts will choose to abort rather than run the risk of delivering a baby whose birth will be the subject of criminal investigation and sanctions. ${ }^{144}$ Surely this is not the outcome sought by right-to-life supporters of such prosecutions. If abortion restrictions are enacted and enforced as states respond to Webster, the pregnant addict may find herself choosing between an illegal abortion and an "illegal" delivery. Both mother

Lynn Bremer, who discussed her cocaine addiction with her obstetrician during prenatal office visits, describes herself as "a perfect example of someone who tried to reach out, and it's all coming back in my face . . . . I feel betrayed . . . . Everyone I talked to about my drug problem has been subpoenaed." Hoffman, supra note 2, at 55 , col. 1 .

${ }^{142}$ Such a right has been found by at least one state court. See In re Baby X, 97 Mich. App. 111, 115, 293 N.W.2d 736, 739 (1980) (stating that "a child has a legal right to begin life with a sound mind and body" (citing Womack v. Buchhorn, 384 Mich. 718, 725, 187 N.W.2d 218, 222 (1971))).

${ }^{143}$ Criminal sanctions are not likely to deter involuntary addictive behavior, but they may deter the voluntary behavior of seeking medical care. On the deterrent effect of threatened criminal sanctions on women seeking prenatal care, see Mariner, Glantz \& Annas, supra note 78, at 37 (stating that "[ $t$ ]here is reason to believe that women will avoid prenatal delivery care if detection of their drug use could lead to their arrest or loss of child custody"); Paltrow, supra note 6, at $44-45$ (noting that "prosecutions and convictions deter pregnant women from getting what little health care is available ... [and further that] women who do seek care are often too frightened to speak openly to their doctors about their problems"). But see Hoffman, supra note 2, at 57, col. 4 (noting comments of Muskegon General Hospital staff psychologist Cheryl Gawkowski that some pregnant addicts have sought drug treatment because of their fear of incarceration, while others have avoided prenatal care because of this same fear).

${ }^{144}$ See Paltrow, supra note 6, at 42. 
and child are likely to suffer either way, as the mother faces prosecution and the child loses any chance for a healthy life.

It is no exaggeration to state that the nation is deeply concerned about drug abuse. News reports and incidents of daily urban life barrage us with the horrors of addiction. ${ }^{145}$ Drug-addicted babies are the smallest victims in a social system characterized by violence and desperation. The babies of drug addicts are not, however, the only ones who may suffer the ill consequences of maternal behavior during pregnancy: the deleterious effects of alcohol ${ }^{146}$ and tobacco ${ }^{147}$ on fetuses have also been well documented. Widespread and insidious as illegal drug use is, liquor and cigarettes are even more accessible and widely used. If the primary objective of prosecuting women who deliver drug-exposed babies is to foster

${ }^{145}$ For interesting descriptions of the American drug subculture, see Bourgois, Just Another Night on Crack Street, N.Y. Times, Nov. 12, 1989, § 6 (Magazine), at 53; O'Rourke, Taking Dougs-Seriously, Rolling STONE, Nov. 30, 1989, at 57 (1989).

${ }^{146}$ Fetal alcohol syndrome (FAS) is the name given to the set of abnormalities resulting from maternal alcohol use during pregnancy. The syndrome is characterized by the presence of one or more of the following developmental defects:

(1) low birth weight and small size with failure to catch up in size or weight;

(2) mental retardation, with an average IQ in the 60s; and (3) a variety of birth defects, with a large percentage of cardiac abnormalities. The fetuses are very quiet in utero, and there is an increased frequency of breech presentations [which may lead to delivery complications]. There is a higher incidence of delayed postnatal growth and behavior development. The risk factors are appreciably higher when more than 6 drinks are ingested each day.

CuRRent Medical Diagnosis \& TREATMENT 662 (M. Krupp, S. Schroeder \& L. Tierney eds. 1987). Infants who exhibit FAS suffer from irreversible, long-term sequelae such as growth deficiencies and are likely to have difficulty in school. See, e.g., Current Pediatric Diagnosis \& Treatment 92 (C. Kempe, H. Silver, D. O'Brien \& V. Fulginiti 9th ed. 1987) (noting that the severity of outcome is not influenced by socioeconomic or educational factors). For a description of a family's attempts to deal with an adopted son's FAS complications, see M. DORRIS, THE BROKEN CORD (1989).

${ }^{147}$ The fetal effects of maternal cigarette smoking can be the same as the effects of maternal drinking. See CuRRENT MEdiCAL DiaGNOSIS \& TREATMENT, supra note 146 , at 662 .

Maternal smoking has been conclusively associated with decreased birth weight at every gestational age after 30 weeks .... [I]nvestigators have found that light smoking as well as heavy smoking . .. is associated with increased perinatal death . . . . Preliminary results of follow-up for 5 years have shown an increase in postneonatal deaths, hospital admissions, physical and mental impairments, and respiratory and skin diseases in children of smoking compared to nonsmoking mothers.

CuRRENT PEDIATRIC Diagnosis \& TREATMENT, supra note 146, at 92-93. 
fetal well-being, prosecutions of women who smoke cigarettes or drink while pregnant is a logical extension. ${ }^{148}$

Why have women who smoke and drink while pregnant largely avoided the prosecutions leveled at their drug-addicted counterparts? The answer may be found in society's unwillingness to tolerate drugs and drug users, in contrast with its general acceptance of alcohol and tobacco. Drugs are illegal while liquor and cigarettes are not. ${ }^{149}$ The legality distinction fails in the context

148 This extension is feared by civil libertarians and others concerned with women's rights. "Will women next be arrested if they smoke ...? Where do we draw the line and who will do the monitoring?" asks a staff attorney at the ACLU Women's Rights Project. Punishing Pregnant Addicts, supra note 54, at E5, col. 5. It should be noted that since 1984 cigarette packages may display the warning: "Smoking By Pregnant Women May Result In Fetal Injury, Premature Birth, And Low Birth Weight." I5 U.S.C. § 1333(a)(1) (1988). Pregnant women who smoke can no longer defend their actions by stating that they didn't know that smoking was bad for their babies.

The Oregon legislature failed to enact a statute criminalizing alcohol consumption by pregnant women. See Development in the Law, supra note 34, at $224 \&$ n.5. A public defender in Melanie Green's hometown of Rockford, Illinois, found that the local hospital had referred no FAS cases to the court system. See Linn, supra note 12, at 24.

In January 1990, a resident of Laramie County, Wyo. who drank while pregnant was charged with child abuse. The woman, four to five months pregnant when charged, had previously borne a child who suffered from FAS. See Pregnant Woman in Wyoming Faces Child Abuse Charges for Drinking, Phila. Inquirer, Jan. 22, 1990, at A2, col. 3. Charges were dropped because the prosecution was unable to prove that the fetus had been injured as a result of the mother's alleged drinking. See Child-Abuse Case Dismissed in Wyoming, Wash. Times, Feb. 2, 1990, at A7. The woman's baby appeared to be healthy when he was born in June. See Woman Once Charged With Abuse of Fetus Gives Birth, UPI, June 18, 1990, BC cycle, Regional News, Colo. (LEXIS, Nexis library, UPST90 file).

Recent federal legislation mandates that on and after the end of the twelvemonth period following November 18, 1988, all alcoholic beverages sold or distributed in the United States must bear the warning that "According to the Surgeon General, women should not drink alcoholic beverages during pregnancy because of the risk of birth defects." 27 U.S.C. $\$ 215$ (a) (1988).

149 Plymouth County Prosecutor William C. O'Malley relies on the illegality of drugs to distinguish the current wave of prosecutions from any possible extension into prosecutions of women who use legal substances. See Punishing Pregnant Addicts, supra note 54, at E5, cols. 3-4. "I can't foresee the prosecution of a case where the underlying facts are not illegal. I don't see myself as a pregnancy cop. I don't think that's the role of the DA." Wong, DA Calls for Guidelines in Fetal Injury Cases, Boston Globe, Nov. 4, 1989, at 25, col.2. O'Malley has also characterized these prosecutions as "protection of a child from physical abuse." See Punishing Pregnant Addicls, supra note 54 , at E5, col. 3 .

It is apparent that children of women who smoke or drink during pregnancy suffer "abuse" similar to that endured by the children of illegal drug users. See supro notes $146-47$ and accompanying text. In addition, the debate over the legalization of drugs such as marijuana and cocaine has recently been reopened. See generally 
of maternal prosecutions, however, because most successful prosecutions of drug-addlicted mothers have been based on laws prohibiting the delivery of drugs to a minor; ${ }^{150}$ similar statutes regulate the sale of alcoholic beverages ${ }^{151}$ and cigarettes ${ }^{152}$ to minors. If the schoolyard crack dealer and the pregnant crack addict may be prosecuted under the same statute, there is no reason why the liquor store clerk who sells to an underage customer and the pregnant alcoholic should not face the same liability under an analogous statute. Perhaps such prosecutions will follow as the logical extension of the current prosecutorial trend. That this has not yet occurred may be symptomatic of the nation's rage and desperation in the face of a seemingly intractable drug epidemic-such strong emotions are not engendered by the health epidemics of smoking and drinking. In addition, addiction to drugs, especially crack, is perceived as a plague of the urban poor whereas "everyone" smokes and drinks. If prosecutions for the fetal effects of drugs are aimed at the middle class, society's attitude toward these prosecutions may change. ${ }^{153}$

\section{Drug Treatment: An Alternative to Criminal PROSECUTION}

Increasing the availability of drug treatment programs tailored to the needs of women would more humanely and effectively address the problem of drug-exposed babies. Prosecutors have asserted that their goals are to get mothers into drug rehabilitation programs and to foster the birth of healthy babies. ${ }^{154}$ Indeed, women convicted of delivering drugs to their babies prenatally may

France, Should We Fight or Switch, 76 A.B.A. J. (1990) (questioning the utility of the war on drugs). If these drugs were legalized, there would be no ground for maternal prosecutions based on the illegality of substances used during pregnancy, in the absence of specific statutes directed at pregnant women.

150 See, e.g., FLA. STAT. ANN. § 893.13(1)(c) (West 1976 \& Supp. 1989) (making it "unlawful for any person 18 years of age or older to deliver any controlled substance to a person under the age of 18 years"). (1989).

151 See, e.g., ALASKa STAT. § 04.16.051 (1989); ARIZ. REV. STAT. ANN. § 4-241

152 See, e.g., ALA. CODE § 13A-12-3 (1975); ARK. STAT. ANN. § 5-27-227 (1987);

FLA. STAT. ANN. \$ 859.06 (West 1976); GA. CODE ANN. § 16-12-171 (1988).

153 Evidence indicates that the incidence of crack use by middle-class urban and suburban whites is increasing. See supra note 137. For a discussion of the discriminatory nature of current prosecutions, see supra text accompanying notes 13338.

${ }^{154}$ See supra notes $110 \& 112-13$ and accompanying text. 
be sentenced to attend drug treatment programs. ${ }^{155}$ Ironically, a criminal conviction may be required to help these women obtain the social services that they are unable to avail themselves of by choice. ${ }^{156}$

Pregnant addicts who seek drug treatment face frustration when they confront an overburdened social welfare system that is largely unresponsive to their needs. Women are routinely turned away from programs that exclude pregnant women, pregnant women on Medicaid, or pregnant crack abusers on Medicaid. ${ }^{157}$ Many residential treatment programs will not permit mothers to keep their children with them, ${ }^{158}$ thereby forcing a woman to forgo either treatment or her children. Many choose to delay treatment, because they fear the consequences of relinquishing their children to the welfare system. ${ }^{159}$ The failure of many programs to accommodate children is one facet of the male orientation of most programs, ${ }^{160}$. which were designed to serve male convicts and which have not adjusted their emphasis in response to the increasing number of female drug addicts. ${ }^{161}$ Drug treatment is often punitive and confrontational, and this style may be particularly ineffective for women: "It's not necessary to humiliate a substance-abusing woman; she already has lost her self-esteem."162

The lack of treatment programs for women may lead them to criminal prosecution despite their best intentions and efforts. One pregnant heroin addict in Butte County, California, was motivated by fear of fetal harm to seek drug treatment ${ }^{163}$ and, through persistence and determination, she gained admittance to an outpatient methadone maintenance clinic in Sacramento. After

155 See supra text accompanying note 12.

156 See Johnsen, From Driving to Drugs: Governmental Regulation of Pregnant Women's Lives After Webster, 138 U, PA. L. REv. 179, $214-15$ (1989); Hoffman, stupra note 2, at 57 ("Why is it that we have to make women criminals before we can get them drug treatment?" (quoting ACLU attorney Kary Moss)).

${ }^{157}$ See Diesenhouse, Drug Trealment is Scarcer Than Ever for Women, N.Y. Times, Jan. 7, 1990, at E26, col. 1. In November of 1989, the ACLU Women's Rights Project filed a lawsuit on behalf of women who had been refused admission to drug treatment programs in New York. See Paltrow, supja note 6, at 47 n.45.

${ }^{158}$ Only 50 of about 7,000 programs nationwide provide child and obstetric care to female patients. See Paltrow, supra note 6, at 47 n.45. col. 1 .

${ }^{159}$ See Tracy, Women Suffer Most From Drugs, Phila. Inquirer, Nov. 27, 1988, at 7E,

\footnotetext{
160 See id.

161 See Diesenhouse, supra note 157, at E20, col. 3.

162 Tracy, supra note 159 , at $7 \mathrm{E}$, col. 3 .

${ }^{163}$ See One Drug-Using Mother's Story, supra note 110.
} 
months of attending the program, which required her to travel 140 miles round trip each day, she fell behind in her payments and lost her only available means of transportation. Following sound medical advice, she went back to using heroin, because a sudden withdrawal from drugs might have been fatal to her fetus. Soon after she gave birth and discussed her drug problem with hospital personnel, her baby was taken away from her by Child Protective Services and the district attorney announced plans to prosecute her. ${ }^{164}$ If this woman had been able to attend an affordable treatment program close to her home, she might have overcome her drug problem, kept her baby, and not been subject to prosecution.

Successful treatment programs for women must provide residential care for mothers ancl children. One such program is New Image, "a therapeutic cornmunity for homeless, addicted women and their children ${ }^{165}$ in Philadelphia. This program reported a dropout rate of $50 \%$ in its first year of operation, which is lower than expected. ${ }^{166}$ Parenting training, psychological assessments, and a series of workshops on development of life skills and jobreadiness complement drug therapy at this program. ${ }^{167}$ Other innovative community programs have been developed in Miami, Los Angeles, and Chicago. ${ }^{168}$ Pending federal legislation may increase funding for drug treatment programs designed to serve women addicts, especially during pregnancy. ${ }^{169}$

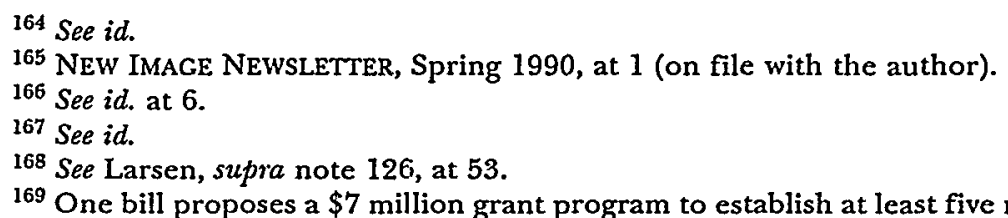
residential treatment programs for addicted mothers and their children, allowing federal funds previously appropriated for waiting-list reduction to be used to provide treatment services to pregnant and post-partum women, and establishing the National Resource and Information Center for Perinatal Addiction. See S. 2649, 101st Cong., $2 d$ Sess. (1990). Another includes provisions to 1) establish a $\$ 120$ million "family preservation program" providing grants to states for multidisciplinary services for families at risk of drug and alcohol abuse; 2) expand Medicaid to cover non-hospital residential and outpatient drug and alcohol treatment and related case management for Medicaid-eligible women of childbearing age; 3) give drug- or alcohol-exposed children priority in Head Start programs; and 4) order the Department of Education to expand special education programs to cover pre-school and elementary school children born affected by alcohol or drugs. See S. 2559, 101st Cong., 2d Sess. (1990). Still another includes provisions to establish a $\$ 200$ million grant program to fund inpatient, outpatient, and residential treatment programs for pregnant and postpartum women. At least $40 \%$ of the funds must go to residential programs where $60 \%$ of the women are in treatment under court or agency order. See S. 2505, 101st 


\section{CONCLUSION}

The recent wave of prosecutions of women who deliver drugexposed babies represents a flawed approach to a critical social problem. These prosecutions flagrantly violate the Constitution by denying defendants their due process rights of notice and fair warning. Moreover, the prosecutions represent judicial enlargement of existing statutes without regard for legislative intent or for the legislature's role in defining crimes. In addition; women's rights have been further eroded by these prosecutions as courts follow Webster's lead in asserting a compelling interest in fetal well-being that may come at the expense of women's health and welfare. Criminal theory is also flouted by, the current prosecutions: involuntary behavior is punished, the major goal of deterrence is not promoted, and criminogenesis results as the criminal justice system intrudes into the realm of medical and social services.

The moral outrage and prosecutorial resources aimed at women whose children are drug-exposed may be more effective if directed against the conditions that breed drug abuse and against the suppliers of drugs who essentially prey on the insatiable needs of addicts. A reduction in the available supply of drugs, coupled with education about the harmfulness of drugs, would be a more humane and potentially successful approach to this intractable problem. There is a dearth of drug treatment facilities for the poor, especially for pregnant crack addicts. If such services were provided without resort to criminalization and prosecution, more women might overcome their drug habits while suffering no infringement of their constitutional rights. The solution to the social tragedy of drug use by pregnant women does not lie in strained interpretations of the law that create more harm than good,

Cong., 1st Sess. (1990). Finally, a fourth proposes the establishment of a $\$ 50$ million grant program to fund pilot projects in five states providing outreach, education, and treatment services to pregnant and post-partum women and their infants. See S. 1414, 101st Cong. (1989). To receive funding, states must require health care providers to report "substance abused" infants, criminalize giving birth to one, and require a mandatory three-year rehabilitation sentence to women convicted of this crime. See $i d$. 
